\title{
Credit Rating Agency Regulation after the UK’s European Union Membership Referendum
}

** This is a pre-publication version of this article. The Published version "Daniel Cash 'Credit Rating Agency Regulation after the UK’s European Union Membership Referendum' [2016] 37 The Company Lawyer 10” is available online on WestLaw UK or from Thomson Reuters DocDel service (http://www.sweetandmaxwell.co.uk/our-business/docdel.aspx) as of September 2016.

Daniel Cash*

\begin{abstract}
In response to the decision by British voters to leave the European Union in the recent referendum, this article discusses what may lie ahead for the regulation of the credit rating industry in the U.K. With the withdrawal from the Union meaning that the U.K. must now establish its own distinct Laws that will govern the Rating Industry, having relied upon the EU beforehand, understanding what may affect the approach taken is of concern for this short article
\end{abstract}

\section{Introduction}

On the $23^{\text {rd }}$ of June 2016 the U.K. went to the polls to decide whether to remain in or leave the European Union; in the early hours of the following morning it was announced that the U.K. would be leaving the Union. Writing immediately after the breaking news of the seemingly seismic decision, this short article discusses what the decision to leave may mean for credit rating agency regulation. Whilst there are a number of factors that are still to be

* Lecturer in Law, Aston University (details forthcoming) 
played out, for better or for worse, the probable reality of the U.K. having to govern all of its financial service sectors itself can be seen to be both potentially positive and potentially negative. Perhaps the biggest question facing the U.K. and her immediate future is whether the political realm will have enough capital to introduce meaningful rules and reforms given its break from the E.U., and in this particular case its break from the European Securities and Markets Authority (ESMA), or whether the danger of alienating important financial players during a period of increasing turbulence, in addition to the need to protect and advance the City of London more than ever, will prompt politicians, legislators and regulators to operate an excessively lenient regulatory regime that threatens our long-term future. These are the issues that will be covered in this short piece.

\section{The U.K.'s Regulation of the Credit Rating Industry before the $23^{\text {rd }}$}

In short, an understanding of the U.K.'s regulation of credit rating agencies can be attained by looking at the European Union regulations, because in 2010 the U.K. incorporated a statutory instrument referred to as 'The Credit Rating Agencies Regulations 2010’1 and as such chose to allow the EU to set regulations for the rating industry, as part of its membership to the Union. Any meaningful analysis of the EU's regulations concerning the rating industry is certainly beyond the scope of this short article, but there are many resources in the literature, whether in brief or extensive form ${ }^{2}$, that can provide the relevant details. The headlines though are that the EU has incorporated three major pieces of legislation for the ratings

\footnotetext{
${ }^{1}$ Financial Services and Markets: The Credit Rating Agencies Regulations 2010 SI. 906/2010

${ }^{2}$ For a brief analysis see Timothy Edwards Credit Rating Agencies Regulations: Briefing Paper [2016] SN05603 House of Commons Library. For an academic analysis of the European Union regulations see Raquel G Alcubilla and Javier R del Pozo Credit Rating Agencies on the Watch List: Analysis of European Regulation (OUP 2012).
} 
industry, known as $C R A I$, $I I$, and $I I I^{3}$, which saw the agencies formally regulated by the Union for the first time, and also represented, in part, the motivation for the establishment of a new sector-wide regulatory body in the form of the European Securities and Markets Authority (ESMA).

In the U.S. the main financial regulator, the Securities and Exchange Commission (SEC), has used a number of relatively small punishments against the agencies that it has at its disposal, including fines in the region of tens of millions of dollars and cease-and-desist orders ${ }^{4}$. In addition to this, the U.S. Treasury Department recently fined Standard \& Poor’s \$1.375 billion for defrauding investors, which represents the largest financial penalty ever given to a credit rating agency (we still await to see the action to be taken against Moody's for the same crime $)^{5}$. Yet, in Europe ESMA has been extremely timid. To date, the largest fine given by ESMA to a rating agency has been $€ 30,000$, given to Dominion Bond Rating Service (DBRS) for 'record-keeping failures' ${ }^{6}$. This relative tepidness is particularly representative of the lack of willingness to seriously punish the agencies when we consider the extraordinary effects that rating agency transgressions have had on the EU member states in terms of mass downgrades and subsequent mass financial bailouts.

\footnotetext{
${ }^{3}$ Regulation (EU) No 1060/2009 [2009] OJ L302/1; Regulation (EU) No 513/2011 [2011] OJ L145/30; Regulation (EU) No 462/2013 [2013] OJ L146/1. There was also a significant Directive which contributed to the direction of CRA related regulation in the EU, Directive 2013/14/EU [2013] OJ L145/1.

${ }^{4}$ For the details of the Treasury Department's actions see Department of Justice 'Justice Department and State Partners Secure \$1.375 Billion Settlement with S\&P for Defrauding Investors in the Lead Up to the Financial Crisis’ [2015] Department of Justice: Office of Public Affairs (Feb. 3). For the punishments given by the SEC see Securities and Exchange Commission Order Instituting Administrative and Cease-and-Desist Proceedings, Pursuant to Section 8A of the Securities Act of 1933 and Sections 15E (d) and 21C of the Securities Exchange Act of 1934, Making Findings, and Imposing Remedial Sanctions and a Cease-and-Desist Order [2015] Release No. 9705; 74104, File No. 3-16348.

${ }^{5}$ Matt Robinson and David McLaughlin 'S\&P Ends Legal Woes Paying \$1.5 Billion Fine to U.S., States’ [2015] Bloomberg (Feb. 3). http://www.bloomberg.com/news/articles/2015-02-03/s-p-ends-legal-woes-with-15-billion-penalty-with-u-s-states [Accessed 24/06/16]

${ }^{6}$ European Securities and Markets Authority ESMA fines DBRS Ratings Ltd. For internal control failings: Press Release (2015) ESMA/2015/1050 https://www.esma.europa.eu/sites/default/files/library/2015/11/20151050_esma_fines_dbrs_for_internal_control_failings.pdf [Accessed 24/06/16]
} 
So, this is the agency that the U.K. has followed in regulating the rating industry. Through the Credit Rating Agency Regulations incorporated in 2010, the U.K. does have certain powers, mostly to investigate what it deems to be potential breaches of EU law within its borders, but for the most part the role of the U.K. governmental agencies is to supervise and ensure the observance of EU laws. For example, the Regulations state that '[The Authority] may... direct a credit rating agency to take such specified steps as are necessary for the purpose of securing its compliance with the EC Regulation...'7. This supervisory function, when combined with the U.K.'s attachment to a regime that has demonstrated no particular deterrent to rating agency transgressions, is unfortunately a telling testament to the U.K.'s regulation of the rating industry whilst it was a part of the European Union. Now that is no longer the case, the question is what is the potential future for the U.K.'s regulation of the rating industry?

\section{The U.K.'s Regulation of the Credit Rating Industry after the $23^{\text {rd }}$}

It is obvious that in writing this piece, on the day of the result of the U.K.'s European Union membership referendum, there is so much that is yet to be determined. On the announcement of the result of the referendum the British Prime Minister, David Cameron, announced that he was resigning from his post which means that even the direction of the ruling political party in the U.K. is uncertain at this time. So, with that in mind I will not attempt to illustrate some perceived vision of how the regulatory regime will come to be in this post-referendum situation, but there are a few things which must be discussed at this politically, and socially

\footnotetext{
${ }^{7}$ Credit Rating Agencies Regulations (n 1) 19 (1)(a)
} 
volatile time; however, with political and social turbulence comes the potential to enact positive social changes so that possibility is also worth discussing.

It is assumed here that the U.K. will have to create its own rules and legislation for the governing of the credit rating industry. Simply relying on regulations that were created to supplement existing EU law will not do in relation to such a societally-important financial sector. Also, the pressing need for the country to alleviate the inevitable crashing of the pound that followed the referendum result and also the need to protect and further the jewel in the crown, the City of London, means that established legislation is surely forthcoming. So, how may that legislation affect the rating industry?

In order to forecast the regulatory mood toward the agencies it is important to look at the pressures affecting a given country (or Union). For example, the EU is so vulnerable to the wrath of the rating agencies, like we saw with the mass downgrades after the financial crisis, that incorporating impactful reform that may lessen the profitability of the agencies is not really an option in Europe, which may explain why the punishment selected by ESMA has been so underwhelming. This potentially explains why the U.S. takes the lead in regulating the agencies, because in addition to the U.S. being the home of the agencies they also have a more solid foundation with which to repel the actions of the largest agencies; the downgrading of U.S. debt to AA+ by S\&P in 2011 did not lead to disaster like many had feared $^{8}$. Yet, the factors potentially affecting the U.K.'s ability to enact meaningful reform are many. The separation from the EU means that the U.K. must put the City of London, and

\footnotetext{
${ }^{8}$ Alexandra Scaggs ‘S\&P Affirms U.S. AA+ Credit Rating, Maintains Stable Outlook’ [2015] Bloomberg (Jun. 10) http://www.bloomberg.com/news/articles/2015-06-10/s-p-affirms-u-s-aa-credit-rating-maintains-stableoutlook [Accessed 24/06/16]
} 
its entire financial service sector, at the forefront of its regulatory thinking, so the mind-set will have to be 'how can this sector be made to be as profitable as possible?' rather than 'how can this sector be made to be as socially beneficial as possible?' - these two mind-sets are not the same thing 9 . This need to stabilise the country and start to rebuild its prosperity, when viewed against the reality that the U.K. is dependent upon its financial services sector, means that the likelihood is that the post-referendum landscape is going to be particularly welcoming and beneficial to the financial services sector, which naturally translates into extraordinarily light-touch regulation. The question then is 'is light-touch regulation appropriate given that the Financial Crisis was less than a decade ago?'

It is foreseeable that the Bank of England, via the Prudential Regulation Authority, will take the lead in regulating the ratings industry given its importance to systemic stability (although arguably a case could also be made for the Financial Conduct Authority to take the lead).

This is potentially the case furthermore because the ability to devolve the responsibility to the EU has now been removed, and the severity of rating agency transgression could severely damage the revival of the British economy, which means that the U.K. establishment must be seen to take control of this important sector, and placing the PRA at the forefront would achieve that aim. However, the real litmus test will be seen in the sentiment invoked by the legislation that will be coming for this particular industry, and also in what regulator is entrusted with the job of supervising this important industry.

\section{Conclusion}

\footnotetext{
${ }^{9}$ For more on this understanding see Mike Feintuck 'Regulatory Rationales Beyond the Economic: In Search of the Public Interest' in Robert Baldwin, Martin Cave, and Martin Lodge The Oxford Handbook of Regulation (OUP 2012).
} 
The referendum on the $23^{\text {rd }}$ of June has the very real potential of being a defining moment in the modern history of the United Kingdom. Leaving aside for one moment the extraordinary ramifications concerning political leadership, the rumoured break-up of the United Kingdom, and the subsequent relationship with its European neighbours, the future of financial regulation in the U.K. is potentially standing at a precipice; beneath all of the sensationalist news stories surrounding this decision, what sentiment will the legislators take?

There are two views in this regard, and which one resonates with the reader is perhaps indicative of one's constitution. In an optimistic world the U.K. could decide to take advantage of this regulatory-fertile post-referendum era and establish impactful reform that would place the safety of the British economy at the forefront of its thinking. By reducing the capacity of rating agencies to protect themselves against financial penalties, by incorporating larger financial penalties for gross misconduct, or even by starting criminal proceedings against CRA managers who knowingly defrauded investors, the U.K. would be establishing a long-term vision that would protect British society from the iniquities of the rating industry, whilst also increasing the reputational capital of the agencies via a meaningful deterrent (in a perfect world agencies would be trusted to be accurate more if the penalties for not doing so were extreme).

However, in a pessimistic world, the U.K. could succumb to the large number of factors that are developing in the post-referendum era that make submitting to the will of the financial sector a priority. The centrality of the financial service sector to the fortunes and advancement of the United Kingdom already dictates that the establishment must be lenient towards the sector, but now that the U.K. must flourish on its own, developing trade- 
agreements without the support of the economic bloc it has been attached to for over 40 years, it is not unreasonable to suggest that the post-referendum era will be defined by its leniency towards the financial sector. The decision to leave the EU or not was inconsequential when compared to the sentiment that legislators and politicians may have towards the financial sector; leaving the EU has the potential to be extraordinarily beneficial to the advancement of British society and its relationship to its financial service sector. However, whilst some may hope that this will turn out to be the case, the likelihood is that the severance from the EU will spark an era that is incredibly lenient towards a sector that led the world to the brink of financial ruin just 8 years ago - this leniency may make the decision taken by the British public on the $23^{\text {rd }}$ of June a particularly costly one to society in the long run.

\section{Keywords}

Credit Rating Agencies; EU Referendum; Economic Conditions; Financial Regulation. 